\title{
Application of Propolis Extract in Gelatin Coatings as Environmentally Friendly Method for Extending the Shelf Life of Pork Loin
}

\author{
Monika Marcinkowska-Lesiak*, Iwona Wojtasik-Kalinowska, Anna Onopiuk, Magdalena Zalewska (D) and \\ Andrzej Poltorak
}

check for updates

Citation: Marcinkowska-Lesiak, M.; Wojtasik-Kalinowska, I.; Onopiuk, A.; Zalewska, M.; Poltorak, A.

Application of Propolis Extract in Gelatin Coatings as Environmentally Friendly Method for Extending the Shelf Life of Pork Loin. Coatings 2021, 11,979. https://doi.org/10.3390/ coatings11080979

Academic Editor: Jaejoon Han

Received: 7 July 2021

Accepted: 16 August 2021

Published: 17 August 2021

Publisher's Note: MDPI stays neutral with regard to jurisdictional claims in published maps and institutional affiliations.

Copyright: (c) 2021 by the authors. Licensee MDPI, Basel, Switzerland. This article is an open access article distributed under the terms and conditions of the Creative Commons Attribution (CC BY) license (https:/ / creativecommons.org/licenses/by/ $4.0 /)$.
Department of Technique and Food Development, Institute of Human Nutrition Sciences, Warsaw University of Life Sciences, Nowoursynowska 159c Street, 32, 02-776 Warsaw, Poland; iwona_wojtasik_kalinowska@sggw.edu.pl (I.W.-K.); anna_onopiuk@sggw.edu.pl (A.O.); magdalena_zalewska@sggw.edu.pl (M.Z.); andrzej_poltorak@sggw.edu.pl (A.P.)

* Correspondence: monika_marcinkowska_lesiak@sggw.edu.pl

\begin{abstract}
This study evaluates the effects of gelatin coating enriched with ethanolic propolis extract (PE) at $1 \%, 2 \%$ or $3 \%(w / v)$ on the quality parameters of pork meat during storage at $2{ }^{\circ} \mathrm{C}$. Physical ( $\mathrm{pH}$, weight loss, color) and chemical parameters (percentage contents of metmyoglobin (MetMb), along with thiobarbituric acid reactive substances (TBARS)) were measured, and microbiological (total aerobic plate count (TAPC)) analysis, as well as consumer evaluation, was carried out every four days during the storage period of twelve days. The results indicated that the proposed treatments affected $(p<0.05)$ the quality characteristics of meat samples. The high prevention of physicochemical alterations and maximum inhibition of microorganisms was obtained for samples stored in gelatin coatings containing $2 \%$ and 3\% PE. Additionally, despite a slight deterioration in odor on Day 4 in the $\mathrm{P}_{3}$ group, no negative changes in overall acceptability of the $\mathrm{P}_{2}$ and $\mathrm{P}_{3}$ groups compared to uncoated samples were observed. The obtained results indicate a significant role of propolis extract incorporation into gelatin packaging to extend the shelf life of stored pork.
\end{abstract}

Keywords: propolis; edible coatings; gelatin; pork; meat quality

\section{Introduction}

Production of edible coatings (ECs) and films (EFs) is becoming more and more prevalent because of their global availability, attractive price and biodegradability [1]. They are defined as thin layers of edible materials providing a barrier to mass transfer (gases, moisture, flavors, etc.) between food and the surrounding atmosphere [2]. Thus, it is assumed that the use of ECs and EFs might extend the shelf life of perishable products such as meat and reduce postconsumer packaging waste $[3,4]$. The main difference among them is that coatings are formed directly on the product, while films are independent structures obtained outside the product $[5,6]$. Nonetheless, both can be prepared on the basis of biopolymers from biomass (starch, chitosan, pectins, casein, whey, collagen, gelatin, zein, soy protein, gluten, waxes, fats, oils), biobased monomers (polylactide and other polyesters) and polymers of microbial origin (bacterial cellulose, marine algae cellulose, xanthine, pullulan, curdlan). The most popular materials for the production of edible packaging are still proteins of plant or animal origin, lipids and polysaccharides [3,7,8]. Moreover, in recent years, it has been pointed out that the addition of bioactive compounds might improve the functional properties of edible biopolymers and thus extend the shelf life of the products on which they have been applied [9]. However, taking into account the variety of stored products, used biopolymers and incorporated compounds, further research in this area is required.

To date, many types of edible coatings have been applied to the surface of meat products to improve their quality during storage [10-15] According to Herring et al. [16], gelatin 
coatings have great potential in pork preservation because they delay lipid and protein oxidation and heme iron conversion, which occurs in meat during storage. However, similarly to polysaccharides, protein coatings exhibit relatively high values of water vapor permeability, which can be associated with their inherent hydrophilicity and the use of hydrophilic plasticizers $[2,3,8]$. Nevertheless, it has been observed that the properties of gelatin coatings can be improved by, for example, oil incorporation [17] or the addition of constituents with antioxidant and antimicrobial properties [14,18].

One of such substances may be propolis, which is a mixture of tree and bush resin and bee gland secretions and is characterized by antioxidant, antibacterial, antifungal, antiviral, antitumor and anti-inflammatory properties [19-21]. The most numerous and best-known group of its compounds are polyphenols, including phenolic acids and flavonoids. Propolis also includes terpenoids, waxes, polysaccharides and micronutrients such as iron, copper, silicon, magnesium, selenium, phosphorus and silicon [22]. Among its compounds, caffeic acid, esters of phenolic acids, flavonoids, kaempferol, quercetin, caffeoylquinic acid derivatives, propol and artepillin $C$ show a particularly high antioxidant activity [23-25]. A previous study reported that edible coatings with propolis can be used to preserve the quality of chicken [26], beef [27], fish [28] or even fruit [29] and vegetables [30].

Although gelatin coatings and propolis have potential in extending the shelf life of pork meat, their combined effect on its quality has not yet been studied. Based on the previous study, their application could be an innovative approach to prolong the shelf life of meat without the addition of chemical preservatives. Thus, the objective of this work was to evaluate the effect of gelatin coatings incorporated with selected concentrations of propolis ethanolic extract ( $1 \%, 2 \%$ and $3 \%$ ) in preserving the quality of pork stored in refrigerated conditions for twelve days.

\section{Materials and Methods}

\subsection{Materials}

Propolis was obtained from an apiary located in a village in Mazowieckie Voivodeship (Wilkowyja, Poland) and frozen $\left(-20^{\circ} \mathrm{C}\right)$ until use. Pork skin gelatin (bloom $=175$ ), glycerol (99\% purity) and other used chemicals and reagents of analytical grade were purchased from Sigma-Aldrich (St. Louis, MO, USA). Pork loins (M. longissimus thoracis et lumborum) were obtained from a local slaughter facility (Zakłady Mięsne Olewnik PLC, Sierpc, Poland) within two days of slaughter and transported in cold conditions to the Warsaw University of Life Sciences (Warsaw, Poland).

\subsection{Propolis Extract Preparation}

The ethanol-extracted propolis (PE) was prepared by adding $70 \%$ ethanol $(v / v)$ to $100 \mathrm{~g}$ of ground crude propolis to a final volume of $1000 \mathrm{~mL}$ solution. Then, the macerate was left at room temperature for 7 days, shaking at least several times per day. After this period, the mixture was filtered through Whatman No. 4 filter paper. The resulting supernatant was concentrated under vacuum in a rotary evaporator at $40{ }^{\circ} \mathrm{C}$ until $80 \%$ volume reduction (Rotavapor R-3, BÜCHI, Flawil, Switzerland). The total phenolic content (TPC) in obtained PE and its DPPH (2,2-diphenyl-1-picrylhydrazyl) radical scavenging capacity assay were evaluated according to the methods described by Półtorak et al. [31]. The obtained values were $927.32 \pm 12.75 \mathrm{mg}$ gallic acid equivalent $/ 100 \mathrm{~g}$ and $90.77 \pm 1.71 \%$ radical scavenging activity, respectively.

\subsection{Preparation of Gelatin Coating Solutions}

To prepare the $10 \%(w / v)$ coating solutions, the required quantities of gelatin were added to distilled water at $60{ }^{\circ} \mathrm{C}$ with continuous stirring for $30 \mathrm{~min}$ to allow the powder to dissolve. After cooling the solutions to $35{ }^{\circ} \mathrm{C}$, propolis extract was added at different concentrations of $0 \%(\mathrm{P} 0), 1 \%(w / v)\left(\mathrm{P}_{1}\right), 2 \%(w / v)\left(\mathrm{P}_{2}\right)$ and $3 \%(w / v)\left(\mathrm{P}_{3}\right)$ and homogenized for $3 \mathrm{~min}$ at $1200 \mathrm{rpm}$ (ULTRA-TURRAX homogenizer, T18 Basic, IKA Werke, Germany). 


\subsection{Meat Coating Procedure}

Each from 6 pork pieces, $M$. longissimus thoracis et lumborum was prepared by removing the external fat and connective tissue and cutting into sections according to MarcinkowskaLesiak et al. [17]. The obtained slices, after weighing, were next coated by dipping into the prepared gelatin-based coating solutions for 2 min based on five formulations: $\mathrm{C}$ (control, uncoated pork loins), $\mathrm{P}_{1}$ (gelatin-coated pork loins with the addition of $1 \%$ propolis extract to gelatin coating), $\mathrm{P}_{2}$ (gelatin-coated pork loins with the addition of $2 \%$ propolis extract to gelatin coating) and $\mathrm{P}_{3}$ (gelatin-coated pork loins with the addition of $3 \%$ propolis extract to gelatin coating). In order to remove excess coating solution, samples were allowed to drain for another 2 min under clean air flow. Next, all groups were reweighted, packaged in a styrofoam tray with a polyvinyl chloride overwrap and stored in a refrigerator at $2{ }^{\circ} \mathrm{C} \pm 1{ }^{\circ} \mathrm{C}$ until analysis on Days $0,4,8$ and 12 . All measurements were carried out in six replications for each storage day and type of used coating.

\subsection{Quality Evaluation of Pork Meat}

\subsection{1. $\mathrm{pH}$ Measurement}

The $\mathrm{pH}$ of pork loins was measured potentiometrically using a $\mathrm{pH}$ meter with a glass electrode (Model 205, Testo, Lenzkirch, Germany) calibrated against buffers of $\mathrm{pH} 4.0$ and 7.0. Three measurements were made by direct injection of an electrode into each sample of the same temperature to a depth of $2 \mathrm{~cm}$.

\subsubsection{Weight Loss}

The weight loss (\%) of samples (WL) was calculated as the difference in meat weight before and after storage, according to the following formula:

$$
\mathrm{WL}(\%)=\frac{\left(\mathrm{W}_{0}-\mathrm{W}_{\mathrm{x}}\right) \times 100}{\mathrm{~W}_{0}}
$$

where $W_{0}$ is the weight of the sample before storage $(\mathrm{g})$ and $\mathrm{W}_{\mathrm{x}}$ is the weight of the sample after 4,8 and 12 days $(\mathrm{g})$.

\subsubsection{Color Measurement}

The color parameters of stored pork loins were determined in the $L^{*} a^{*} b^{*}$ system using Chromameter CR-400 (Konica Minolta Inc., Tokyo, Japan) calibrated on the CIE LAB color space system using a white plate $\left(\mathrm{L}^{*}=98.45, \mathrm{a}^{*}=-0.10, \mathrm{~b}^{*}=-0.13\right)$. Five color measurements of different areas of each sample surface were taken performed with a spot diameter of $8 \mathrm{~mm}$, a D65 illuminant (color temperature $=6500 \mathrm{~K}$ ) and an observer angle of $2^{\circ}$. Based on the $L^{*}$ (lightness), $a^{*}$ (red/green) and $b^{*}$ (blue/yellow) values of each sample, after storage, a total color difference $(\Delta \mathrm{E})$ in relation to Day 0 was determined using the following formula:

$$
\Delta \mathrm{E}(-)=\sqrt{\left(\mathrm{L}_{\mathrm{dx}}-\mathrm{L}_{\mathrm{d} 0}\right)^{2}+\left(\mathrm{a}_{\mathrm{dx}}-\mathrm{a}_{\mathrm{d} 0}\right)^{2}+\left(\mathrm{b}_{\mathrm{dx}}-\mathrm{b}_{\mathrm{d} 0}\right)^{2}}
$$

where $\mathrm{L}_{\mathrm{d} 0}, \mathrm{a}_{\mathrm{d} 0}$ and $\mathrm{b}_{\mathrm{d} 0}$ are the color parameters of the sample before storage, and $\mathrm{L}_{\mathrm{dx}}, \mathrm{a}_{\mathrm{dx}}$ and $b_{\mathrm{dx}}$ are the color parameters of the sample after storage.

\subsubsection{Metmyoglobin Content}

Percentage contents of metmyoglobin (MetMb) in meat were determined according to the method described by Krzywicki [32] with modifications by Tang, Faustman and Hoaglan [33]. The absorbances of the prepared solutions were measured at $582 \mathrm{~nm}$ (A582), $525 \mathrm{~nm}$ (A525) and $503 \mathrm{~nm}$ (A503) using a Spark $10 \mathrm{M}$ multimode microplate reader (Tecan Group Ltd., Männedorf, Switzerland). Triplicate measurements were made for 
each meat sample, and the percentage of metmyoglobin was calculated based on the following formula:

$$
\operatorname{MetMb}(\%)=-0.159 R_{1}-0.085 R_{2}+1.262 R_{3}-0.520
$$

where $\mathrm{R}_{1}=\mathrm{A} 582 / \mathrm{A} 525, \mathrm{R}_{2}=\mathrm{A} 557 / \mathrm{A} 525$ and $\mathrm{R}_{3}=\mathrm{A} 503 / \mathrm{A} 525$.

\subsubsection{Lipid Oxidation}

Thiobarbituric acid reactive substances (TBARS) in samples were determined according to the method by Pikul et al. [34] with modifications described by Półtorak et al. [31] using the SparkTM 10 M spectrometer (Tecan Group Ltd., Männedorf, Switzerland). TBARS values were expressed as 2-thiobarbituric acid reactive substances (TBARS) in mg malondialdehyde (MDA) per $\mathrm{kg}$ of meat using a standard curve prepared from tetramethoxypropane. Three replications were made for each measurement.

\subsubsection{Microbiological Analysis}

In order to determine the total aerobic plate count (TAPC), a series of ten-fold dilutions from the initial dilution of samples were prepared. For this purpose, $10 \mathrm{~g}$ of meat was homogenized using ULTRA-TURRAX homogenizer (T18 basic, IKA Werke, Staufen, Germany) with $90 \mathrm{~mL}$ of sterile $1.5 \%$ peptone water for $2 \mathrm{~min}$. Then, $1 \mathrm{~mL}$ of aliquots from each dilution was dispensed into Petri dishes, to which a molten plate count agar (PCA) was added. The inoculated plates were incubated at $30^{\circ} \mathrm{C}$ for $72 \mathrm{~h}$. Obtained results were ultimately converted into a logarithm of the number of colony-forming units per gram of meat $(\log \mathrm{CFU} / \mathrm{g})$. Triplicate measurements were made for each sample.

\subsubsection{Meat Quality Acceptance}

The meat quality acceptance of raw pork loin during storage was conducted according to the semiconsumer scaling method under standard conditions by a panel of 24 well-trained consumers under the same conditions (room temperature, individual booths, light of about 500 lux). Pieces of meat from each group (dimensions $=20 \times 20 \mathrm{~mm}$, temperature $=2{ }^{\circ} \mathrm{C} \pm 1{ }^{\circ} \mathrm{C}$ ) were presented to the panel in covered white plastic plates (5 min intervals, samples encoded). In each of the analyzed days, all samples were served once to each panelist (the serving order was randomized). The nonstructured $10 \mathrm{~cm}$ intensity scale ranging from the lowest acceptability (value of 1.0) to the highest acceptability (value of 10.0) of each analyzed attribute was used. Consumers were asked to place a mark between each limit value to denote their evaluation of color, odor and overall acceptability. The individual observations were interpreted using the measuring device to record the distance from the left to the panelists' marks.

\subsection{Statistical Analysis}

Statistical analysis was carried out using Statistica 13.3 (StatSoft Inc., Tulsa, OK, USA) after allowing for the randomization specified and blocking according to an animal (the data were analyzed using an individual loin from each carcass as the experimental unit). The results were analyzed using two-way ANOVA with treatment (T), storage time (ST) and interaction $(\mathrm{T} \times \mathrm{ST})$ as the factors. The differences between groups were tested according to the Tukey's means test $(p<0.05)$. The results in tables are presented as mean values and standard deviations (SD).

\section{Results and Discussion}

Results achieved in this study demonstrated that different treatments $(\mathrm{T})$ and prolongation of the storage time (ST) of pork loins, as well as the interaction between them, significantly affected (Table 1) most of the analyzed parameters. 
Table 1. Test probabilities for tee physical, chemical and microbiological parameters of pork loins: multiaspect variance analysis.

\begin{tabular}{cccc}
\hline \multirow{2}{*}{ Item } & \multicolumn{2}{c}{ Effect } & Interaction T $\times$ ST \\
\cline { 2 - 3 } & Treatment (T) & Storage Time (ST) & $* * *$ \\
WH & $* * * 1$ & $* * *$ & $* * *$ \\
$\mathrm{~L}^{*}$ & $* * *$ & $* * *$ & $* * *$ \\
$\mathrm{a}^{*}$ & $* * *$ & $* * *$ & $* * *$ \\
$\mathrm{~b}^{*}$ & $* * * * *$ & $* * *$ \\
$\Delta \mathrm{E}$ & $\mathrm{NS}$ & $* * *$ & $* * *$ \\
TBARS & $*$ & $* * *$ & $* * *$ \\
MetMb & $* * *$ & $* * *$ & $* * *$ \\
TAPC & $\mathrm{NS}$ & $* * *$ & $* * *$ \\
color & $\mathrm{NS}$ & $* * *$ & $* * *$ \\
odor & $* * *$ & $*$ & $* * *$ \\
overall acceptance & $* * *$ & $* * *$ &
\end{tabular}

${ }_{1 *} p<0.05 ;{ }^{* *} p<0.01,{ }^{* * *} p<0.001$, NS: not significant.

\section{1. $p H$ Measurement}

The quality of meat and its culinary and processing suitability depend largely on its $\mathrm{pH}$ value. In the conducted research, meat with $\mathrm{pH}_{45}$ and $\mathrm{pH}_{24}$ values characteristic for normal meat, without undesired quality characteristics such as pale, soft and exudative (PSE) or dark, firm and dry (DFD), was used (data not shown). Obtained data (Table 2) indicate that treatment $(\mathrm{T})$ and storage time $(\mathrm{ST})$ had significant $(p<0.05)$ effects on the $\mathrm{pH}$ values of stored meat.

Table 2. Effect of the applied coatings on the physical parameters of pork loins during storage.

\begin{tabular}{|c|c|c|c|c|c|}
\hline \multirow{2}{*}{ Parameters } & \multirow{2}{*}{ Treatments } & \multicolumn{4}{|c|}{ Storage Time (Days) } \\
\hline & & 0 & 4 & 8 & 12 \\
\hline \multirow{5}{*}{$\mathrm{pH}$} & $\mathrm{C}$ & $5.56^{\mathrm{aA} 1} \pm 0.01$ & $5.60^{\mathrm{abA}} \pm 0.02$ & $5.64^{\mathrm{bB}} \pm 0.01$ & $5.75^{\mathrm{cC}} \pm 0.03$ \\
\hline & $\mathrm{P}_{0}$ & $5.56^{\mathrm{aA}} \pm 0.01$ & $5.56^{\mathrm{aA}} \pm 0.01$ & $5.58^{\mathrm{aA}} \pm 0.02$ & $5.63^{\mathrm{bB}} \pm 0.01$ \\
\hline & $\mathrm{P}_{1}$ & $5.56^{\mathrm{aA}} \pm 0.01$ & $5.55^{\mathrm{aA}} \pm 0.03$ & $5.55^{\mathrm{aA}} \pm 0.04$ & $5.63^{\mathrm{bAB}} \pm 0.04$ \\
\hline & $\mathrm{P}_{2}$ & $5.56^{\mathrm{aA}} \pm 0.01$ & $5.57^{\mathrm{aA}} \pm 0.02$ & $5.56^{\mathrm{aA}} \pm 0.02$ & $5.60^{\mathrm{aAB}} \pm 0.03$ \\
\hline & $\mathrm{P}_{3}$ & $5.56^{\mathrm{aA}} \pm 0.01$ & $5.55^{\mathrm{aA}} \pm 0.04$ & $5.58^{\mathrm{aA}} \pm 0.02$ & $5.58^{\mathrm{aA}} \pm 0.02$ \\
\hline \multirow{5}{*}{ Weight Loss (\%) } & $\mathrm{C}$ & - & $3.43^{\mathrm{aB}} \pm 0.35$ & $5.15^{\mathrm{bC}} \pm 0.24$ & $7.92^{\mathrm{cC}} \pm 0.38$ \\
\hline & $\mathrm{P}_{0}$ & - & $2.33^{\mathrm{aA}} \pm 0.2$ & $3.47^{\mathrm{bB}} \pm 0.37$ & $4.56^{\mathrm{cB}} \pm 0.28$ \\
\hline & $\mathrm{P}_{1}$ & - & $2.23^{\mathrm{aA}} \pm 0.21$ & $2.98^{\mathrm{bAB}} \pm 0.17$ & $4.34^{\mathrm{cAB}} \pm 0.29$ \\
\hline & $\mathrm{P}_{2}$ & - & $2.31^{\mathrm{aA}} \pm 0.50$ & $3.01^{\mathrm{bAB}} \pm 0.17$ & $4.21^{\mathrm{cAB}} \pm 0.26$ \\
\hline & $\mathrm{P}_{3}$ & - & $2.16^{\mathrm{aA}} \pm 0.11$ & $2.96^{\mathrm{bA}} \pm 0.20$ & $4.00^{\mathrm{cA}} \pm 0.18$ \\
\hline \multirow{5}{*}{$\mathrm{L}^{*}(\%)$} & $\mathrm{C}$ & $57.10^{\mathrm{cA}} \pm 0.98$ & $55.59 \mathrm{cA} \pm 0.28$ & $52.35^{\mathrm{bA}} \pm 0.51$ & $49.68^{\mathrm{aA}} \pm 0.61$ \\
\hline & $\mathrm{P}_{0}$ & $57.10^{\mathrm{cA}} \pm 0.98$ & $56.08^{\mathrm{cAB}} \pm 0.77$ & $53.95^{\mathrm{bB}} \pm 0.85$ & $51.80^{\mathrm{aB}} \pm 0.76$ \\
\hline & $\mathrm{P}_{1}$ & $57.10^{\mathrm{bA}} \pm 0.98$ & $57.17^{\mathrm{bB}} \pm 0.66$ & $55.20^{\mathrm{aB}} \pm 0.56$ & $53.84^{\mathrm{aC}} \pm 0.42$ \\
\hline & $\mathrm{P}_{2}$ & $57.10^{\mathrm{bA}} \pm 0.98$ & $57.19^{\mathrm{bB}} \pm 0.64$ & $54.69^{\mathrm{aB}} \pm 0.78$ & $54.18^{\mathrm{aC}} \pm 0.36$ \\
\hline & $\mathrm{P}_{3}$ & $57.10^{\mathrm{bA}} \pm 0.98$ & $57.14^{\mathrm{bB}} \pm 0.44$ & $54.57^{\mathrm{aB}} \pm 0.79$ & $54.14^{\mathrm{aC}} \pm 0.71$ \\
\hline \multirow{5}{*}{$a^{*}$} & $\mathrm{C}$ & $7.27^{\mathrm{bA}} \pm 0.45$ & $6.79^{\mathrm{bA}} \pm 0.13$ & $6.01^{\mathrm{aA}} \pm 0.46$ & $5.75^{\mathrm{aA}} \pm 0.12$ \\
\hline & $\mathrm{P}_{0}$ & $7.27^{\mathrm{bA}} \pm 0.45$ & $7.03^{\mathrm{bA}} \pm 0.43$ & $6.18^{\mathrm{aA}} \pm 0.42$ & $6.26^{\mathrm{aAB}} \pm 0.33$ \\
\hline & $\mathrm{P}_{1}$ & $7.27^{\mathrm{bA}} \pm 0.45$ & $7.14^{\mathrm{bA}} \pm 0.24$ & $6.32^{\mathrm{aA}} \pm 0.26$ & $6.42^{\mathrm{aAB}} \pm 0.28$ \\
\hline & $\mathrm{P}_{2}$ & $7.27^{\mathrm{bA}} \pm 0.45$ & $7.17^{\mathrm{bA}} \pm 0.25$ & $6.61^{\mathrm{abAB}} \pm 0.37$ & $6.31^{\mathrm{aAB}} \pm 0.20$ \\
\hline & $\mathrm{P}_{3}$ & $7.27^{\mathrm{aA}} \pm 0.45$ & $7.11^{\mathrm{aA}} \pm 0.29$ & $7.14^{\mathrm{aB}} \pm 0.41$ & $6.88^{\mathrm{aB}} \pm 0.17$ \\
\hline \multirow{5}{*}{$b^{*}$} & $\mathrm{C}$ & $3.78^{\mathrm{aA}} \pm 0.20$ & $7.93^{b C} \pm 0.27$ & $8.59^{\mathrm{bcB}} \pm 0.40$ & $9.02^{\mathrm{cB}} \pm 0.25$ \\
\hline & $\mathrm{P}_{0}$ & $3.78^{\mathrm{aA}} \pm 0.20$ & $6.35^{\mathrm{bA}} \pm 0.21$ & $7.62^{c} \pm 0.34$ & $8.11^{\mathrm{cA}} \pm 0.14$ \\
\hline & $P_{1}$ & $3.78^{\mathrm{aA}} \pm 0.20$ & $6.39^{\mathrm{bA}} \pm 0.14$ & $7.34^{\mathrm{cA}} \pm 0.27$ & $7.64^{\mathrm{cA}} \pm 0.40$ \\
\hline & $\mathrm{P}_{2}$ & $3.78^{\mathrm{aA}} \pm 0.20$ & $6.83^{\mathrm{bAB}} \pm 0.29$ & $7.27^{b c A} \pm 0.25$ & $7.70^{\mathrm{cA}} \pm 0.29$ \\
\hline & $\mathrm{P}_{3}$ & $3.78^{\mathrm{aA}} \pm 0.20$ & $7.01^{\mathrm{bB}} \pm 0.13$ & $7.30^{\mathrm{bA}} \pm 0.34$ & $7.60^{\mathrm{bA}} \pm 0.30$ \\
\hline
\end{tabular}


Table 2. Cont.

\begin{tabular}{|c|c|c|c|c|c|}
\hline \multirow{2}{*}{ Parameters } & \multirow{2}{*}{ Treatments } & \multicolumn{4}{|c|}{ Storage Time (Days) } \\
\hline & & 0 & 4 & 8 & 12 \\
\hline \multirow{5}{*}{$\Delta \mathrm{E}$} & $\mathrm{C}$ & - & $4.62^{\mathrm{aB}} \pm 0.33$ & $7.12^{b C} \pm 0.42$ & $9.41^{\mathrm{cC}} \pm 0.60$ \\
\hline & $\mathrm{P}_{0}$ & - & $3.06^{\mathrm{aA}} \pm 0.31$ & $5.38^{\mathrm{bA}} \pm 0.58$ & $7.13^{\mathrm{cB}} \pm 0.58$ \\
\hline & $P_{1}$ & - & $2.88^{\mathrm{aA}} \pm 0.28$ & $4.44^{\mathrm{bA}} \pm 0.32$ & $5.35^{\mathrm{bA}} \pm 0.49$ \\
\hline & $\mathrm{P}_{2}$ & - & $3.24^{\mathrm{aA}} \pm 0.25$ & $4.55^{\mathrm{bA}} \pm 0.47$ & $5.21^{\mathrm{bA}} \pm 0.30$ \\
\hline & $\mathrm{P}_{3}$ & - & $3.40^{\mathrm{aA}} \pm 0.17$ & $4.54^{\mathrm{bA}} \pm 0.35$ & $5.03^{\mathrm{bA}} \pm 0.52$ \\
\hline
\end{tabular}

1a-d: mean values marked with various lowercase letters show statistically significant differences within rows ( $p<0.05) ;{ }^{A-D}:$ mean values marked with various capital letters show statistically significant differences within columns $(p<0.05)$; C-uncoated pork loins; $\mathrm{P}_{0}$-gelatin-coated pork loins; $\mathrm{P}_{1}$-gelatin-coated pork loins with the addition of $1 \%$ propolis extract to gelatin coating; $\mathrm{P}_{2}-$ gelatin-coated pork loins with the addition of $2 \%$ propolis extract to gelatin coating; $\mathrm{P}_{3}$-gelatin-coated pork loins with the addition of $3 \%$ propolis extract to gelatin coating.

The increase in the $\mathrm{pH}$ of stored meat may be associated with the increased activity of proteolytic enzymes (calpains, cathepsins B and L, peptidases), causing a gradual release of peptides, amino acids and ammonia [35], or with microbial growth [36]. Beginning from Day 8, coated samples were characterized by lower $\mathrm{pH}$ values compared to those in the control group. Observed changes in the $\mathrm{pH}$ of the coated samples in relation to the $\mathrm{pH}$ of the control group stored in the air atmosphere could be due to the limitation of the range of proteolytic changes in muscle proteins, which lead to gradual alkalization of the stored meat [37]. Additionally, on Day 12, pork loins coated with gelatin containing 3\% propolis extract were characterized by lower values of the analyzed parameters than samples coated only with gelatin $(p<0.05)$. The observed changes in the $\mathrm{pH}$ value at the end of storage may be related to the antioxidant and antimicrobial properties of propolis [38], limiting changes in proteolysis and microbial growth in stored meat. The above results are consistent with other studies indicating a decrease in the $\mathrm{pH}$ values of stored fish fillets [28] or chicken breast meat [26] in the case of using coatings with propolis extract.

\subsection{Weight Loss}

Weight loss of pork loins studied in this work increased within 12 days at $2{ }^{\circ} \mathrm{C}$ (Table 2). The results also show that the treatment had a significant $(p<0.05)$ effect on values of the analyzed parameters during refrigerated storage (Table 2). Although weight loss tended to increase for all samples, its values in the control group were greater than in the coated samples, regardless of the storage time. Although gelatin films are characterized by poor water vapor permeability values, they have good barrier properties against oxygen $[39,40]$. It can be assumed that the amount of meat weight loss during storage depended on the rate of water evaporation and the leakage of meat juice related to hydrolysis reactions and microbial spoilage in the presence of oxygen. Reduction of weight loss in gelatincoated pork meat compared to control samples was previously indicated in the work of Antoniewski et al. [41] and Herring et al. [16]. Additionally, from Day 8, pork loins from the $\mathrm{P}_{3}$ group were characterized by lower values of weight loss compared to the $\mathrm{P}_{0}$ group. At the end of storage, values of the analyzed parameters in the $\mathrm{P}_{3}$ group decreased by almost $49.5 \%$ and $12.3 \%$ in relation to values in uncoated samples and samples coated only by gelatin, respectively. Research has indicated that gelatin films tend to cluster water within their polymer matrix [42]. Based on the obtained results, it could be concluded that polyphenolic compounds (TPC $=927.32 \pm 12.75 \mathrm{mg}$ gallic acid equivalent $/ 100 \mathrm{~g}$ ) found in the used propolis extract by interaction with the gelatin matrix reduced its hygroscopicity [38] and thus limited water loss of the coated meat. Additionally, other researchers indicated that water vapor permeability of films can decrease by propolis extract incorporation [43,44].

\subsection{Color Measurement}

Interaction between treatments (T) and storage time (ST) significantly affected all color parameters $\left(\mathrm{L}^{*}, \mathrm{a}^{*}, \mathrm{~b}^{*}\right)$ of stored samples, and color difference $(\Delta \mathrm{E})$ was calculated on 
their basis (Table 2). During 12 days of storage, the lightness $\left(\mathrm{L}^{*}\right)$ of all samples decreased significantly $(p<0.05)$. Additionally, beginning from Day 8 , uncoated meat was darker than coated samples $(p<0.05)$, which may be related to the highest water loss observed in the C group [17] and the oxidation of oxymyoglobin to metmyoglobin [45]. At the end of storage, samples from the $\mathrm{P}_{1}, \mathrm{P}_{2}$ and $\mathrm{P}_{3}$ groups were characterized by the slightest decline in lightness, not exceeding $6 \%$ with respect to the coating day, probably due to the antioxidant capacity of the propolis extract [46] and thus its ability to reduce the degradation of meat color by delaying the oxidation reaction [47]. Coatings, especially those with the addition of propolis, also increased the stability of the red color ( $\mathrm{a}^{*}$ ) of stored samples $(p<0.05)$. The highest decrease in redness in relation to Day 0 (to 1.52) was recorded for the control group $(p<0.05)$. Additionally, only in the case of the $\mathrm{P}_{3}$ group was no decrease $(p \geq 0.05)$ in the analyzed parameters observed during the twelve days of storage. A similar effect in retarding changes in $a^{*}$ values of stored Nemipterus japonicus fillets using chitosan coatings incorporated with propolis extract was previously observed by Ebadi et al. [45]. Contrary to the brightness and redness of the samples, an increase in yellowness was observed in all analyzed groups after storage $(p<0.05)$, which may be due to the progressive oxidation reactions in all samples. Although the smallest changes in $b^{*}$ values during the entire storage period were observed for the $\mathrm{P}_{3}$ group, at the end of storage, there were no significant differences in $b^{*}$ values between all coated samples. Additionally, it is noteworthy that on Day 4, samples from this group were characterized by higher values of the $b^{*}$ parameter than samples from the $P_{0}$ and $P_{1}$ groups, which may be due to the incorporated amount of propolis in gelatin. According to Moreno et al. [48], the yellower color of gelatin films with propolis can be explained by the presence of polyphenolic compounds derived from propolis in the biopolymer matrix.

Table 2 also includes the values of the $\Delta \mathrm{E}$ parameter, which expresses the total change in color of all treatments after storage with respect to samples from Day 0. It was observed that during storage, $\Delta \mathrm{E}$ values were increasingly evident for all groups $(p<0.05)$. Beginning from Day 4, the greatest values of the analyzed parameters were noted in the case of uncoated meat, which means its color was the least stable. Additionally, at the end of storage, color changes in $\mathrm{P}_{1}, \mathrm{P}_{2}$ and $\mathrm{P}_{3}$ groups were significantly smaller $(p<0.05)$ than those observed in the P0 group, reaching values below 5.5. Nevertheless, based on the range of the $\Delta \mathrm{E}$ index [49], a color difference was clearly observed in all samples after 12 days $(\Delta \mathrm{E}>3.5)$. These changes may be related to oxidation processes in meat samples and phenolic compounds in propolis extract (927.32 $\pm 12.75 \mathrm{mg}$ gallic acid equivalent/100 g), which can undergo degradation after time.

\subsection{Metmyoglobin Content}

During storage, the percentage content of metmyoglobin (Table 3) gradually increased $(p<0.05)$ in all analyzed groups. Nonetheless, it is assumed that hydrogen bonds in gelatin coatings and films can limit the access of oxygen to meat and thus reduce oxidation of the red oxymyoglobin to brown metmyoglobin [41]. This is in agreement with our results, as beginning from Day 8, uncoated samples were characterized by the highest values of the analyzed parameters $(p<0.05)$. The above study also reveals that the addition of propolis extract (PE) to gelatin coatings helps to reduce the formation of metmyoglobin compared to samples coated with gelatin $(p<0.05)$. This is probably due to the fact that PE addition affected the efficiency of oxidative reactions in stored meat (Table 3) and inhibited the total aerobic plate count (Table 4), which decreased the color stability of the meat. Inhibitory effects of propolis on lipid oxidation and microbiological growth in meat products were confirmed by Reis et al. [50] and Vargas-Sánches et al. [51]. The obtained results also correspond to the results of Rizzolo et al. [52], who stated that active paper incorporated with propolis extract could be suitable to store cooked ham slices. Comparable observations were also confirmed by our previous study [17], which demonstrated that gelatin coatings incorporated with sage and hemp oils can delay the increase in the MetMb content of stored pork. 
Table 3. Effect of the applied coatings on the chemical parameters of pork loins during storage.

\begin{tabular}{|c|c|c|c|c|c|}
\hline \multirow{2}{*}{ Parameter } & \multirow{2}{*}{ Treatments } & \multicolumn{4}{|c|}{ Storage Time (Days) } \\
\hline & & 0 & 4 & 8 & 12 \\
\hline \multirow{5}{*}{ MetMb (\%) } & $\mathrm{C}$ & $20.87^{\mathrm{aA} 1} \pm 0.67$ & $33.51^{b C} \pm 2.63$ & $51.77^{\mathrm{cC}} \pm 1.63$ & $62.07^{\mathrm{dD}} \pm 1.88$ \\
\hline & $\mathrm{P}_{0}$ & $20.87^{\mathrm{aA}} \pm 0.67$ & $30.22^{\mathrm{bBC}} \pm 1.39$ & $46.20^{\mathrm{cB}} \pm 2.63$ & $56.23^{\mathrm{dC}} \pm 1.41$ \\
\hline & $\mathrm{P}_{1}$ & $20.87^{\mathrm{aA}} \pm 0.67$ & $29.12^{\mathrm{bAB}} \pm 1.71$ & $44.78^{\mathrm{cAB}} \pm 2.07$ & $51.93^{\mathrm{dB}} \pm 1.69$ \\
\hline & $\mathrm{P}_{2}$ & $20.87^{\mathrm{aA}} \pm 0.67$ & $27.19^{\mathrm{bAB}} \pm 2.66$ & $43.94^{\mathrm{cAB}} \pm 0.87$ & $49.26^{\mathrm{dAB}} \pm 1.50$ \\
\hline & $\mathrm{P}_{3}$ & $20.87^{\mathrm{aA}} \pm 0.67$ & $26.48^{\mathrm{bA}} \pm 1.46$ & $42.12^{\mathrm{cA}} \pm 1.48$ & $46.92^{\mathrm{dA}} \pm 2.21$ \\
\hline \multirow{5}{*}{ TBARS (mg/100 g) } & $\mathrm{C}$ & $0.12^{\mathrm{aA}} \pm 0.01$ & $0.61^{\mathrm{bD}} \pm 0.03$ & $0.96^{\mathrm{cD}} \pm 0.06$ & $1.68^{\mathrm{dD}} \pm 0.06$ \\
\hline & $\mathrm{P}_{0}$ & $0.12^{\mathrm{aA}} \pm 0.01$ & $0.47^{b C} \pm 0.03$ & $0.83^{\mathrm{cC}} \pm 0.01$ & $1.43^{\mathrm{dC}} \pm 0.05$ \\
\hline & $\mathrm{P}_{1}$ & $0.12^{\mathrm{aA}} \pm 0.01$ & $0.42^{\mathrm{bBC}} \pm 0.02$ & $0.77^{\mathrm{cC}} \pm 0.03$ & $1.44^{\mathrm{dC}} \pm 0.05$ \\
\hline & $\mathrm{P}_{2}$ & $0.12^{\mathrm{aA}} \pm 0.01$ & $0.37^{\mathrm{bAB}} \pm 0.03$ & $0.55^{\mathrm{cB}} \pm 0.03$ & $1.25^{\mathrm{dB}} \pm 0.08$ \\
\hline & $\mathrm{P}_{3}$ & $0.12^{\mathrm{aA}} \pm 0.01$ & $0.30^{\mathrm{bA}} \pm 0.04$ & $0.46^{\mathrm{cA}} \pm 0.03$ & $1.05^{\mathrm{dA}} \pm 0.05$ \\
\hline
\end{tabular}

1a-d: mean values marked with various lowercase letters show statistically significant differences within rows $(p<0.05)$; ${ }^{A-D}:$ mean values marked with various capital letters show statistically significant differences within columns $(p<0.05)$; $C$ - uncoated pork loins; $\mathrm{P}_{0}$-gelatin-coated pork loins; $\mathrm{P}_{1}$-gelatin-coated pork loins with the addition of $1 \%$ propolis extract to gelatin coating; $\mathrm{P}_{2}$-gelatin-coated pork loins with the addition of $2 \%$ propolis extract to gelatin coating; $\mathrm{P}_{3}$-gelatin-coated pork loins with the addition of $3 \%$ propolis extract to gelatin coating.

Table 4. The effect of the applied coatings on chemical parameters of pork loins during storage.

\begin{tabular}{|c|c|c|c|c|c|}
\hline \multirow{2}{*}{ Parameters } & \multirow{2}{*}{ Treatments } & \multicolumn{4}{|c|}{ Storage Time (Days) } \\
\hline & & 0 & 4 & 8 & 12 \\
\hline \multirow{5}{*}{ TAPC (log CFU/g) } & $\mathrm{C}$ & $2.99^{\mathrm{aA} 1} \pm 0.24$ & $4.37^{\mathrm{bD}} \pm 0.17$ & $5.58^{\mathrm{cD}} \pm 0.11$ & $6.96^{\mathrm{dD}} \pm 0.16$ \\
\hline & $\mathrm{P}_{0}$ & $2.99^{\mathrm{aA}} \pm 0.24$ & $3.71^{\mathrm{bC}} \pm 0.20$ & $5.17^{\mathrm{cC}} \pm 0.13$ & $5.53^{\mathrm{dC}} \pm 0.08$ \\
\hline & $\mathrm{P}_{1}$ & $2.99^{\mathrm{aA}} \pm 0.24$ & $3.50^{\mathrm{bBC}} \pm 0.09$ & $4.44^{\mathrm{cC}} \pm 0.15$ & $4.59^{\mathrm{dC}} \pm 0.13$ \\
\hline & $\mathrm{P}_{2}$ & $2.99^{\mathrm{aA}} \pm 0.24$ & $3.39^{\mathrm{bAB}} \pm 0.06$ & $4.27^{\mathrm{cB}} \pm 0.17$ & $4.35^{\mathrm{dB}} \pm 0.10$ \\
\hline & $\mathrm{P}_{3}$ & $2.99^{\mathrm{aA}} \pm 0.24$ & $3.26^{\mathrm{bA}} \pm 0.08$ & $3.95^{\mathrm{cA}} \pm 0.15$ & $4.03^{\mathrm{dA}} \pm 0.13$ \\
\hline
\end{tabular}

1a-d: mean values marked with various lowercase letters show statistically significant differences within rows $(p<0.05) ;{ }^{A-D}:$ mean values marked with various capital letters show statistically significant differences within columns $(p<0.05)$; $\mathrm{C}$-uncoated pork loins; $\mathrm{P}_{0}$-gelatin-coated pork loins; $\mathrm{P}_{1}$ - gelatin-coated pork loins with the addition of $1 \%$ propolis extract to gelatin coating; $\mathrm{P}_{2}$-gelatin-coated pork loins with the addition of $2 \%$ propolis extract to gelatin coating; $\mathrm{P}_{3}$-gelatin-coated pork loins with the addition of $3 \%$ propolis extract to gelatin coating.

\subsection{Lipid Oxidation}

The measurement of substances that cause a color reaction with 2-thiobarbituric acid (TBARS) is one of the basic methods of determining the lipid oxidation process in meat and meat products. Results presented in Table 3 indicate that lipid oxidation of all samples increases with storage time $(p<0.05)$, reaching the highest TBARS values for the control group $(p<0.05)$ in all analyzed days. As assumed, gelatin coatings with low gas permeability reduced lipid oxidation in stored meat [16]. Nevertheless, in high-moisture products such as pork, oxygen permeability of gelatin coatings increases during storage because of the interaction between water and gelatin molecules [53]. In such cases, the appropriate amount of phenolic compounds and scavenging free radicals incorporated into gelatin solutions may be of key importance in preventing lipid oxidation in coated samples. Starting from Day 4 of storage, samples from the $\mathrm{P}_{2}$ and $\mathrm{P}_{3}$ groups were characterized by lower TBARS values than gelatin-coated samples ( $\mathrm{P}_{0}$ group). Based on the obtained results, the addition of $3 \%$ propolis extract to gelatin coatings was able to significantly reduce the rate of lipid oxidation in stored pork loins, resulting in their lowest rancidity compared with other treatments. Compared to Groups $\mathrm{C}$ and $\mathrm{P}_{0}$, TBARS values of $\mathrm{P}_{3}$ samples at the end of storage decreased by $37.5 \%$ and $26.6 \%$, respectively. This is consistent with other studies, owing to the fact that edible films with the addition of propolis, due to polyphenolic compounds, are characterized by high antioxidant activity, which increases with the greater addition of propolis $[44,46,54]$. Similar findings were also reported by Jonaidi Jafari et al. [55] and Mehdizadeh and Mojaddar Langrodi [26], who found that 
incorporation of propolis ethanolic extract to chitosan coatings at the level of 1-2\% resulted in a reduction in TBARS values in stored chicken fillets.

\subsection{Microbiological Analysis}

A high content of protein substances and almost neutral $\mathrm{pH}$ of meat promotes the development of various microflora. The amount of microorganisms and their development in meat depend on many factors, ranging from the method of slaughtering animals to the method of meat storage. Treatment and storage time were the factors affecting the total aerobic plate count (TAPC), an indicator of the microbiological quality of meat (Table 4).

It is assumed that the upper limit for TAPC values in meat that is acceptable should not exceed $7 \log \mathrm{CFU} / \mathrm{g}$ [56]. Although TAPC values significantly increased during storage $(p<0.05)$ for all groups, at the end of storage, only the values in the $C$ group came close to the spoilage limit of meat. Beginning from Day 4 , the values of the analyzed parameters for coated samples were significantly lower $(p<0.05)$ than the control group $(\mathrm{C})$. This was probably due to the fact that gelatin coatings are characterized by low gas permeability [57] and thus provide better results for the inhibition of aerobic flora. In addition, after 8 and 12 days of storage, a significant decrease $(p<0.05)$ in TAPC values compared to the other groups was observed for the samples coated with gelatin containing $2 \%$ and $3 \%$ ethanolic propolis extract. At the end of storage, it was possible to reduce the TAPC values in these groups in the range of $1.6\left(\mathrm{P}_{2}\right)-1.73\left(\mathrm{P}_{3}\right)$ in relation to uncoated meat. Additionally, Nessianpour et al. [58] observed that propolis incorporation in a gelatin matrix led to a reduction in microbial growth of refrigerated Saurida tumboli fillets. These effects can be mainly attributed to the antimicrobial activity of propolis extract related to the presence of polyphenolic compounds inhibiting DNA and RNA synthesis by changing the permeability of the cell membrane of microorganisms [38,59]. What is more, our results are also in line with the research carried out by Shavisi et al. [27], which showed differences in the values of the analyzed parameters of ground beef during storage depending on the concentrations of propolis extract used in polylactic acid (PLA) films.

\subsection{Meat Quality Acceptance}

In terms of acceptance of meat quality, differences were observed between the analyzed groups, regardless of the storage period. All groups were analyzed based on a 10-point nonstructured scale. Coatings modified the color, odor and overall acceptability of refrigerated pork loins. Beginning from Day 8, incorporation of 2\% and 3\% propolis extract to gelatin coatings improved the color of stored meat compared to uncoated samples $(C)$ and gelatin-coated samples $\left(\mathrm{P}_{0}\right)$ (Figure 1 ).

Nonetheless, the largest extract addition to the gelatin coating solution ( $\mathrm{P}_{3}$ group) had a negative effect on meat odor compared to the $P_{0}, P_{1}$ and $P_{2}$ groups (Figure 2). On Day 4 , the odor of samples from the $\mathrm{P}_{3}$ group was assessed slightly worse than the odor of samples from the control group. This may be due to the fact that the addition of $3 \%$ propolis extract to the coating solution could, in the first days of storage, give off an odor that, according to consumers, is different from that of typical pork meat.

This ultimately affected the overall quality scores of all groups (Figure 3). Additionally, Mehdizadeh and Mojaddar Langroodi [26] agreed that when determining propolis dose in coating solutions, it is necessary to take into account the intrinsic flavor of propolis extract. Nevertheless, Figure 3 shows that at the end of storage, samples from the $\mathrm{P}_{1}, \mathrm{P}_{2}$ and $\mathrm{P}_{3}$ groups were characterized by the highest overall quality. Although other authors have demonstrated the positive effect of edible coatings with propolis extract on the sensory quality of fish $[28,59]$, the effect of propolis extract in gelatin coating solutions on pork quality has not been analyzed so far. 


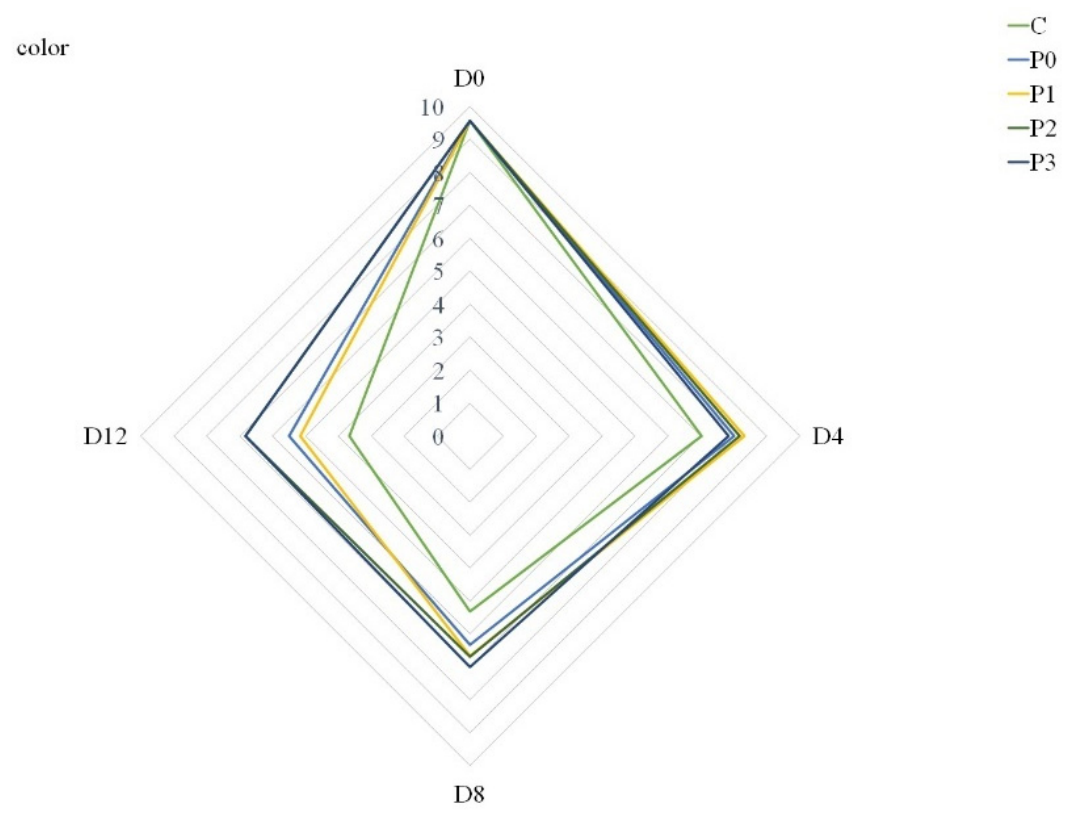

Figure 1. Color of stored samples $\left(\mathrm{C}\right.$ - uncoated pork loins; $\mathrm{P}_{0}$ - gelatin-coated pork loins; $\mathrm{P}_{1}$-gelatincoated pork loins with the addition of $1 \%$ propolis extract to gelatin coating; $\mathrm{P}_{2}$-gelatin-coated pork loins with the addition of $2 \%$ propolis extract to gelatin coating; $\mathrm{P}_{3}$-gelatin-coated pork loins with the addition of 3\% propolis extract to gelatin coating; D0—Day 0; D4—Day 4; D8—Day 8; D12—Day 12).
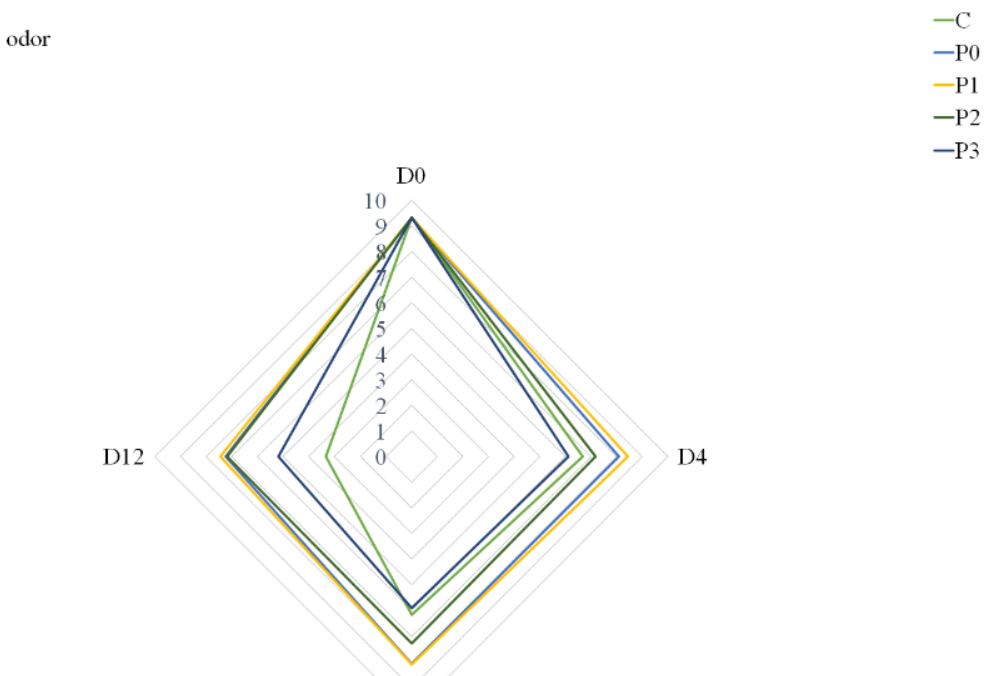

$-\mathrm{C}$
$-\mathrm{P} 0$
$-\mathrm{P} 1$
$-\mathrm{P} 2$
$-\mathrm{P} 3$

D8

Figure 2. Odor of stored samples $\left(\mathrm{C}\right.$ - uncoated pork loins; $\mathrm{P}_{0}$ - gelatin-coated pork loins; $\mathrm{P}_{1}$ - gelatincoated pork loins with the addition of $1 \%$ propolis extract to gelatin coating; $\mathrm{P}_{2}$-gelatin-coated pork loins with the addition of $2 \%$ propolis extract to gelatin coating; $\mathrm{P}_{3}$-gelatin-coated pork loins with the addition of 3\% propolis extract to gelatin coating; D0—Day 0; D4-Day 4; D8—Day 8; D12-Day 12). 


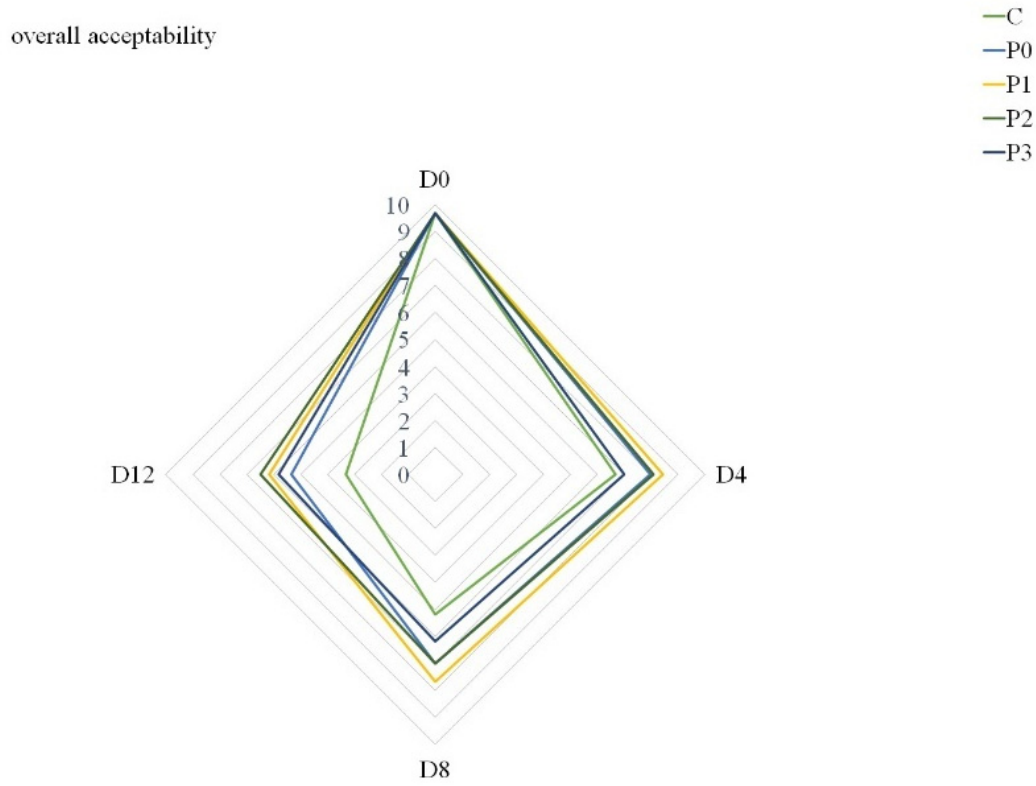

Figure 3. Overall acceptability of stored samples ( $\mathrm{C}$ - uncoated pork loins; $\mathrm{P}_{0}$ - gelatin-coated pork loins; $\mathrm{P}_{1}$-gelatin-coated pork loins with the addition of $1 \%$ propolis extract to gelatin coating; $\mathrm{P}_{2}$-gelatin-coated pork loins with the addition of $2 \%$ propolis extract to gelatin coating; $\mathrm{P}_{3}$-gelatincoated pork loins with the addition of 3\% propolis extract to gelatin coating; D0—Day 0; D4—Day 4; D8-Day 8; D12-Day 12).

\section{Conclusions}

In conclusion, the proposed gelatin coatings with ethanolic propolis extract in an amount equal to $2 \%(w / v)$ or higher have great potential to extend the shelf life of meat, which may be mainly due to the high content of phenolic compounds in propolis (927.32 $\pm 12.75 \mathrm{mg}$ gallic acid equivalent/100 g) and thus its high antioxidant activity $(90.77 \pm 1.71 \% \mathrm{DPPH})$. The use of propolis extract in the amount of $2 \%(w / v)$ and $3 \%(w / v)$ with respect to gelatin solution delayed unfavorable color changes, oxidative processes and the growth of microorganisms in stored pork loins compared to uncoated samples and samples coated only with gelatin. From Day 8, the addition of 3\% propolis extract to the coatings also reduced pork weight loss compared to the $\mathrm{P}_{0}$ group. However, a slight deterioration in the overall acceptance of samples from the $\mathrm{P}_{3}$ group was observed compared to gelatin-coated meat in the initial storage period. Nonetheless, in the $\mathrm{P}_{3}$ group, besides a slight deterioration in odor on Day 4, no negative changes in overall acceptability compared to uncoated samples were observed. Taking the above into consideration, the use of gelatin coatings with propolis incorporation at the level of $2-3 \%$ could be an environmentally friendly and cheap alternative to chemical preservatives to prolong the quality of pork during refrigerated storage. However, particular care should be taken so as not to use excess propolis in coatings, as its characteristic, strong flavor could alter the sensory characteristics of pork meat. Additional research is needed to see if the use of gelatin coatings with the proposed amount of propolis extract can also minimize pork contamination with other microorganisms.

Author Contributions: Conceptualization, M.M.-L., methodology, M.M.-L., software, M.M.-L. and M.Z.; validation, A.O. and I.W.-K.; formal analysis, M.M.-L., A.O., M.Z. and I.W.-K.; investigation, M.Z., M.M.-L.; data curation, A.P.; writing—original draft preparation, M.M.-L. and A.P.; writingreview and editing, M.M.-L. All authors have contributed equally to the development of this article. All authors have read and agreed to the published version of the manuscript.

Funding: This research was financed by the Polish Ministry of Science and Higher Education through funds provided to the Institute of Human Sciences, Warsaw University of Life Sciences (WULS) for scientific research. 
Institutional Review Board Statement: Not applicable.

Informed Consent Statement: Not applicable.

Data Availability Statement: The data presented in this study are available on request from the corresponding author.

Conflicts of Interest: The authors declare no conflict of interest.

\section{References}

1. Chen, W.; Ma, S.; Wang, Q.; McClements, D.J.; Liu, X.; Ngai, T.; Liu, F. Fortification of edible films with bioactive agents: A review of their formation, properties, and application in food preservation. Crit. Rev. Food Sci. Nutr. 2021, 1-27. [CrossRef]

2. Thawien, W. Protein-Based Edible Films: Characteristics and Improvement of Properties. Intech 2012, 43-64. [CrossRef]

3. Pajak, P.; Fortuna, T.; Przetaczek-Roznowska, I. Opakowania jadalne na bazie białek i polisacharydów-Charakterystyka i zastosowanie. Żywność Nauk. Technol. Jakość 2013, 20, 5-18.

4. Suput, D.Z.; Lazic, V.L.; Popovic, S.Z.; Hromis, N.M. Edible films and coatings: Sources, properties and application. Food Feed. Res. 2015, 42, 11-22. [CrossRef]

5. Saberi, B.; Golding, J.; Chockchaisawasdee, S.; Scarlett, C.J.; Stathopoulos, C.E. Effect of Biocomposite Edible Coatings Based on Pea Starch and Guar Gum on Nutritional Quality of "Valencia" Orange During Storage. Starch Stärke 2018, 70, 1700299. [CrossRef]

6. Falguera, V.; Quintero, J.P.; Jiménez, A.; Muñoz, J.A.; Ibarz, A. Edible films and coatings: Structures, active functions and trends in their use. Trends Food Sci. Technol. 2011, 22, 292-303. [CrossRef]

7. Hassan, B.; Chatha, S.A.S.; Hussain, A.I.; Zia, K.M.; Akhtar, N. Recent advances on polysaccharides, lipids and protein based edible films and coatings: A review. Int. J. Biol. Macromol. 2018, 109, 1095-1107. [CrossRef]

8. Galus, S.; Lenart, A. Effect $\mathrm{f}$ protein concentration on kinetics of water vapour adsorption by coatings prepared on the basis of whey protein isolate. Żywność Nauk. Technol. Jakość 2011, 4, 66-73. [CrossRef]

9. Quirós-Sauceda, A.E.; Zavala, J.F.A.; Olivas, G.; González-Aguilar, G.A. Edible coatings as encapsulating matrices for bioactive compounds: A review. J. Food Sci. Technol. 2014, 51, 1674-1685. [CrossRef]

10. Maru, V.R.; Gupta, S.; Ranade, V.; Variyar, P.S. Pullulan or chitosan based active coating by incorporating polyphenols from lemon peel in raw poultry meat. J. Food Sci. Technol. 2020, 1-10. [CrossRef]

11. Lashkari, H.; Halabinejad, M.; Rafati, A.; Namdar, A. Shelf Life Extension of Veal Meat by Edible Coating Incorporated with Zataria multiflora Essential Oil. J. Food Qual. 2020, 2020, 1-8. [CrossRef]

12. Liu, J.; Shibata, M.; Ma, Q.; Liu, F.; Lu, Q.; Shan, Q.; Hagiwara, T.; Bao, J. Characterization of fish collagen from blue shark skin and its application for chitosan-collagen composite coating to preserve red porgy (Pagrus major) meat. J. Food Biochem. 2020, 44, e13265. [CrossRef]

13. Zhang, H.; Liang, Y.; Li, X.; Kang, H. Effect of chitosan-gelatin coating containing nano-encapsulated tarragon essential oil on the preservation of pork slices. Meat Sci. 2020, 166, 108137. [CrossRef] [PubMed]

14. Gallego, M.; Arnal, M.; Talens, P.; Toldrá, F.; Mora, L. Effect of Gelatin Coating Enriched with Antioxidant Tomato By-Products on the Quality of Pork Meat. Polymers 2020, 12, 1032. [CrossRef] [PubMed]

15. Cardoso, G.P.; Andrade, M.P.D.; Rodrigues, L.M.; Massingue, A.A.; Fontes, P.R.; Ramos, A.D.L.S.; Ramos, E.M. Retail display of beef steaks coated with monolayer and bilayer chitosan-gelatin composites. Meat Sci. 2019, 152, 20-30. [CrossRef]

16. Herring, J.L.; Jonnalongadda, S.C.; Narayanan, V.C.; Coleman, S.M. Oxidative stability of gelatin coated pork at refrigerated storage. Meat Sci. 2010, 85, 651-656. [CrossRef] [PubMed]

17. Marcinkowska-Lesiak, M.; Onopiuk, A.; Wojtasik-Kalinowska, I.; Zalewska, M.; Półtorak, A.; Wierzbicka, A. The influence of sage and hemp oils addition to gelatin-based edible coating on the quality features of pork. CyTA J. Food 2020, 18, 719-727. [CrossRef]

18. Jridi, M.; Leticia, M.; Nabil, S.; Aristoy, M.C.; Moncef, N.; Toldrá, F. Effects of active gelatin coated with henna (L. inermis) extract on beef meat quality during chilled storage. Food Control. 2018, 84, 238-245. [CrossRef]

19. Osés, S.; Pascual-Maté, A.; Muiño, M.A.F.; López-Díaz, T.; Sancho, M. Bioactive properties of honey with propolis. Food Chem. 2016, 196, 1215-1223. [CrossRef]

20. Silva, F.R.G.; Matias, T.M.S.; Souza, L.I.O.; Matos-Rocha, T.J.; Fonseca, S.A.; Mousinho, K.; Santos, A.F. Phytochemical screening and in vitro antibacterial, antifungal, antioxidant and antitumor activities of the red propolis Alagoas. Braz. J. Biol. 2019, 79, 452-459. [CrossRef]

21. Seibert, J.B.; Bautista-Silva, J.P.; Amparo, T.R.; Petit, A.; Pervier, P.; Almeida, J.C.D.S.; Azevedo, M.C.; Silveira, B.M.; Brandão, G.C.; de Souza, G.H.B.; et al. Development of propolis nanoemulsion with antioxidant and antimicrobial activity for use as a potential natural preservative. Food Chem. 2019, 287, 61-67. [CrossRef]

22. Anjum, S.I.; Ullah, A.; Khan, K.A.; Attaullah, M.; Khan, H.; Ali, H.; Bashir, M.A.; Tahir, M.; Ansari, M.J.; Ghramh, H.A.; et al. Composition and functional properties of propolis (bee glue): A review. Saudi J. Biol. Sci. 2019, 26, 1695-1703. [CrossRef]

23. Kumazawa, S.; Hamasaka, T.; Nakayama, T. Antioxidant activity of propolis of various geographic origins. Food Chem. 2004, 84, 329-339. [CrossRef]

24. Shimizu, K.; Ashida, H.; Matsuura, Y.; Kanazawa, K. Antioxidative bioavailability of artepillin C in Brazilian propolis. Arch. Biochem. Biophys. 2004, 424, 181-188. [CrossRef] 
25. Banskota, A.H.; Tezuka, Y.; Kadota, S. Recent progress in pharmacological research of propolis. Phytother. Res. $2001,15,561-571$. [CrossRef] [PubMed]

26. Mehdizadeh, T.; Langroodi, A.M. Chitosan coatings incorporated with propolis extract and Zataria multiflora Boiss oil for active packaging of chicken breast meat. Int. J. Biol. Macromol. 2019, 141, 401-409. [CrossRef]

27. Shavisi, N.; Khanjari, A.; Basti, A.A.; Misaghi, A.; Shahbazi, Y. Effect of PLA films containing propolis ethanolic extract, cellulose nanoparticle and Ziziphora clinopodioides essential oil on chemical, microbial and sensory properties of minced beef. Meat Sci. 2017, 124, 95-104. [CrossRef] [PubMed]

28. Marquez, D.G.P.; Fuenmayor, C.A.; Mahecha, H.S. Effect of chitosan-propolis edible coatings on stability of refrigerated cachama (Piaractus brachypomus) vacuum-packed fish fillets. Packag. Technol. Sci. 2018, 32, 143-153. [CrossRef]

29. Ali, A.; Chow, W.L.; Zahid, N.; Ong, M.K. Efficacy of Propolis and Cinnamon Oil Coating in Controlling Post-Harvest Anthracnose and Quality of Chilli (Capsicum annuum L.) during Cold Storage. Food Bioprocess Technol. 2014, 7, 2742-2748. [CrossRef]

30. Del Carmen Martínez-González, M.; Bautista-Baños, S.; Correa-Pacheco, Z.N.; Corona-Rangel, M.L.; Ventura-Aguilar, R.I.; Del Río-García, J.C.; Ramos-García, M.D.L. Effect of Nanostructured Chitosan/Propolis Coatings on the Quality and Antioxidant Capacity of Strawberries During Storage. Coatings 2020, 10, 90. [CrossRef]

31. Poltorak, A.; Marcinkowska-Lesiak, M.; Lendzion, K.; Moczkowska, M.; Onopiuk, A.; Wojtasik-Kalinowska, I.; Wierzbicka, A. Evaluation of the antioxidant, anti-inflammatory and antimicrobial effects of catuaba, galangal, roseroot, maca root, guarana and polyfloral honey in sausages during storage. LWT 2018, 96, 364-370. [CrossRef]

32. Krzywicki, K. Assessment of relative content of myoglobin, oxymyoglobin and metmyoglobin at the surface of beef. Meat Sci. 1979, 3, 1-10. [CrossRef]

33. Tang, J.; Faustman, C.; Hoagland, T.A.C. Food Chemistry and Toxicology Krzywicki Revisited: Equations for Spectro-photometric Determination of Myoglobin Redox Forms in ABSTRACT: Krzywicki 's equations have been widely used for estimating the relative proportions of myoglobin. J. Food Sci. 2004, 69, 717-720. [CrossRef]

34. Pikul, J.; Leszczynski, D.E.; Kummerow, F.A. Evaluation of three modified TBA methods for measuring lipid oxidation in chicken meat. J. Agric. Food Chem. 1989, 37, 1309-1313. [CrossRef]

35. Berardo, A.; Devreese, B.; De Maere, H.; Stavropoulou, D.; Van Royen, G.; Leroy, F.; De Smet, S. Actin proteolysis during ripening of dry fermented sausages at different $\mathrm{pH}$ values. Food Chem. 2017, 221, 1322-1332. [CrossRef]

36. Fik, M.; Leszczyńska-Fik, A. Microbiological and Sensory Changes in Minced Beef Treated with Potassium Lactate and Sodium Diacetate during Refrigerated Storage. Int. J. Food Prop. 2007, 10, 589-598. [CrossRef]

37. Medić, H.; Kušec, I.D.; Pleadin, J.; Kozačinski, L.; Njari, B.; Hengl, B.; Kušec, G. The impact of frozen storage duration on physical, chemical and microbiological properties of pork. Meat Sci. 2018, 140, 119-127. [CrossRef]

38. Yong, H.; Liu, J. Active packaging films and edible coatings based on polyphenol-rich propolis extract: A review. Compr. Rev. Food Sci. Food Saf. 2021, 20, 2106-2145. [CrossRef]

39. Gómez-Estaca, J.; Gómez-Guillén, M.C.; Fernández-Martín, F.; Montero, P. Effects of gelatin origin, bovine-hide and tuna-skin, on the properties of compound gelatin-chitosan films. Food Hydrocoll. 2011, 25, 1461-1469. [CrossRef]

40. Hoque, S.; Benjakul, S.; Prodpran, T.; Songtipya, P. Properties of blend film based on cuttlefish (Sepia pharaonis) skin gelatin and mungbean protein isolate. Int. J. Biol. Macromol. 2011, 49, 663-673. [CrossRef]

41. Antoniewski, M.N.; Barringer, S.A. Meat Shelf-life and Extension using Collagen/Gelatin Coatings: A Review. Crit. Rev. Food Sci. Nutr. 2010, 50, 644-653. [CrossRef]

42. Avena-Bustillos, R.; Olsen, C.; Olson, D.; Chiou, B.; Yee, E.; Bechtel, P.; McHugh, T. Water Vapor Permeability of Mammalian and Fish Gelatin Films. J. Food Sci. 2006, 71, E202-E207. [CrossRef]

43. Mustafa, P.; Niazi, M.B.K.; Jahan, Z.; Samin, G.; Hussain, A.; Ahmed, T.; Naqvi, S.R. PVA/starch/propolis/anthocyanins rosemary extract composite films as active and intelligent food packaging materials. J. Food Saf. 2019, 40, 1-11. [CrossRef]

44. Ulloa, P.A.; Vidal, J.; Dicastillo, C.; Rodriguez, F.; Guarda, A.; Cruz, R.M.S.; Galotto, M.J. Development of poly(lactic acid) films with propolis as a source of active compounds: Biodegradability, physical, and functional properties. J. Appl. Polym. Sci. 2018, 136, 1-11. [CrossRef]

45. Ebadi, Z.; Khodanazary, A.; Hosseini, S.M.; Zanguee, N. The shelf life extension of refrigerated Nemipterus japonicus fillets by chitosan coating incorporated with propolis extract. Int. J. Biol. Macromol. 2019, 139, 94-102. [CrossRef] [PubMed]

46. De Araújo, G.K.P.; De Souza, S.J.; Da Silva, M.V.; Yamashita, F.; Gonçalves, O.H.; Leimann, F.V.; Shirai, M.A. Physical, antimicrobial and antioxidant properties of starch-based film containing ethanolic propolis extract. Int. J. Food Sci. Technol. 2015, 50, 2080-2087. [CrossRef]

47. Verma, A.K.; Chatli, M.K.; Kumar, P.; Mehta, N. Antioxidant and Antimicrobial Activity of Porcine Liver Hydrolysate in Meat Emulsion and Their Influence on Physico-Chemical and Color Deterioration during Refrigeration Storage. J. Food Sci. 2019, 84, 1844-1853. [CrossRef] [PubMed]

48. Moreno, M.A.; Vallejo, A.M.; Ballester, A.-R.; Zampini, C.; Isla, M.I.; López-Rubio, A.; Fabra, M.J. Antifungal edible coatings containing Argentinian propolis extract and their application in raspberries. Food Hydrocoll. 2020, 107, 105973. [CrossRef]

49. Lis, B.; Woźniak, M.; Kiystofiak, T.; Ratajczak, I. Effect of accelerated aging on the color changes of wood treated with eco-friendly formulations based on propolis and silicon compounds. BioResources 2020, 15, 3667-3677. [CrossRef] 
50. Reis, A.; Diedrich, C.; de Moura, C.; Pereira, D.; Almeida, J.F.; da Silva, L.D.; Plata-Oviedo, M.S.V.; Tavares, R.A.W.; Carpes, S.T. Physico-chemical characteristics of microencapsulated propolis co-product extract and its effect on storage stability of burger meat during storage at $-15{ }^{\circ} \mathrm{C}$. LWT 2017, 76, 306-313. [CrossRef]

51. Vargas-Sánchez, R.D.; Torrescano-Urrutia, G.R.; Acedo-Félix, E.; Carvajal-Millan, E.; González-Córdova, A.F.; Vallejo-Galland, B.; Torres-Llanez, M.J.; Sánchez-Escalante, A. Antioxidant and Antimicrobial Activity of Commercial Propolis Extract in Beef Patties. J. Food Sci. 2014, 79, C1499-C1504. [CrossRef] [PubMed]

52. Rizzolo, A.; Bianchi, G.; Povolo, M.; Migliori, C.A.; Contarini, G.; Pelizzola, V.; Cattaneo, T.M. Volatile compound composition and antioxidant activity of cooked ham slices packed in propolis-based active packaging. Food Packag. Shelf Life 2016, 8, 41-49. [CrossRef]

53. Bonilla, J.; Atarés, L.; Vargas, M.; Chiralt, A. Edible films and coatings to prevent the detrimental effect of oxygen on food quality: Possibilities and limitations. J. Food Eng. 2012, 110, 208-213. [CrossRef]

54. Suriyatem, R.; Auras, R.A.; Rachtanapun, C.; Rachtanapun, P. Biodegradable Rice Starch/Carboxymethyl Chitosan Films with Added Propolis Extract for Potential Use as Active Food Packaging. Polymers 2018, 10, 954. [CrossRef] [PubMed]

55. Jafari, N.J.; Kargozari, M.; Ranjbar, R.; Rostami, H.; Hamedi, H. The effect of chitosan coating incorporated with ethanolic extract of propolis on the quality of refrigerated chicken fillet. J. Food Process. Preserv. 2017, 42, e13336. [CrossRef]

56. Ercolini, D.; Russo, F.; Torrieri, E.; Masi, P.; Villani, F. Changes in the Spoilage-Related Microbiota of Beef during Refrigerated Storage under Different Packaging Conditions. Appl. Environ. Microbiol. 2006, 72, 4663-4671. [CrossRef] [PubMed]

57. Ramos, M.; Valdés, A.; Beltrán, A.; Garrigós, M.D.C. Gelatin-Based Films and Coatings for Food Packaging Applications. Coatings 2016, 6, 41. [CrossRef]

58. Nessianpour, E.; Khodanazary, A.; Hosseini, S.M. Shelf Life of Saurida tumbil during Storage at Refrigeration Condition as affected by Gelatin-Based Edible Coatings Incorporated with propolis Extract. Int. J. Food Prop. 2019, 22, 1749-1759. [CrossRef]

59. Siripatrawan, U.; Vitchayakitti, W. Improving functional properties of chitosan films as active food packaging by incorporating with propolis. Food Hydrocoll. 2016, 61, 695-702. [CrossRef] 